\title{
Marine collagen as a source of bioactive molecules. A review
}

Ailén Alemán, Oscar Martínez-Alvarez *

Institute of Food Science, Technology and Nutrition (ICTAN-CSIC)**, Ciudad Universitaria, 28040

Madrid, Spain. Tel: +34915492300; Fax: +34915493627

* Corresponding author. Email address: oscar.martinez@ictan.csic.es

** This Centre has implemented and maintains a Quality Management System which fulfils the requirements of the ISO standard 9001:2008

\begin{abstract}
Skins, scales and bones are the major by-products of the fish-processing industry. These by-products are not regarded as ordinary saleable products and are usually discarded causing a heavy environmental impact. However, they are a good source of collagen. This collagen could be extracted and further enzymatically hydrolysed to liberate physiologically active peptides. Specifically, some collagen-derived peptides may exhibit interesting antioxidant activity, potent antihypertensive activity, antimicrobial activity against different strains of bacteria, protective effect on cartilage, or capacity to stimulate bone formation. Collagen hydrolysates from fish disposals may also exhibit other interesting activities (e.g., satiety, calciotropic, or opioid). The bioactive properties of collagen-derived peptides, and also their resistance to protein digestion, make them potential ingredients of health promoting foods.
\end{abstract}

Keywords: bioactive peptides, by-products, collagen, fish, gelatine, hydrolysates, nutraceuticals.

Short running title: bioactive collagen-derived molecules 


\section{Introduction}

Fish processing waste, which otherwise cause serious environmental pollution, is a promising cost effective collagen source [1]. Fish collagen from skins, bones, fins and scales could be extracted and hydrolysed by chemical pre-treatment and subsequent heating at temperatures higher than $45^{\circ} \mathrm{C}[2,3]$. The mixture of soluble protein and peptides produced by the chemical pre-treatment and subsequent heating could be defined as gelatine. Collagen and gelatine contain bioactive peptides inactive within their sequence which can be released during gastrointestinal digestion or by controlled enzymatic hydrolysis. These collagen- and gelatine-derived peptides may exert a wide variety of physiological activities in the body, and could have potential applications in functional foods.

The interest of processed functional food manufacturing in gelatine hydrolysates has grown in the last years for their potential nutraceutical activity. The term 'nutraceutical' was coined by DeFelice [4] to describe "any substance that is a food or part of a food and provides medical or health benefits, including the prevention and treatment of disease". Interest in nutraceuticals is growing rapidly worldwide, as they are a safe alternative to pharmaceutical drugs, which use is sometimes limited by toxicity or intolerance reactions. Collagen and gelatine hydrolysates could be attractive nutraceuticals for their interesting bioactive properties. The beneficial effect of collagen or gelatine hydrolysates on different diseases has been reported in animal or clinical studies, and actually several supplements including collagen-derived peptides have been patented and are currently commercialised in USA, Japan and Europe. Moreover, hydrolysed gelatine products have received GRAS status (Generally Recognized as Safe) by the US Food and Drug Administration (FDA) [5]. Although mammalian gelatines are widely used in the field of nutraceuticals, the use of gelatines from marine-discarded sources for preparing protein hydrolysates is nowadays increasing, as they are not associated with the risk of outbreaks of bovine spongiform encephalopathy and also meet certain religious requirements of Jewish and Muslim markets.

The resistance of some collagen-derived peptides to protein digestion is one of the most interesting properties of collagen hydrolysates. Several studies focused on the effect of oral intake in both animal and human models have revealed the excellent absorption and metabolism of Hyp-containing peptides. Some of these collagen-derived peptides have revealed biological activity in vivo after absorption from the digestive tract [5]. 
The present article provides a summary on some relevant bioactive activities ascribed to collagen- or gelatine-derived peptides from marine sources. Thus, antioxidative, antihypertensive (ACE inhibitory), antimicrobial, opioid, joint-regenerative, calciotropic and secretagogue activities of collagen and gelatine hydrolysates will be reviewed, as well as other interesting bioactive activities.

\section{Antioxidant activity}

Oxidation is a vital process in aerobic organisms, particularly in vertebrates and humans. However, oxidation leads to the formation of reactive oxygen species (ROS), including free radicals and non-free radical species. Oxidation primarily occurs on unsaturated fatty acids by a free radical-mediated process. The free radicals interact with molecular oxygen to form lipid peroxy radicals. These radicals can abstract a hydrogen atom from adjacent unsaturated fatty acids and produce a hydroperoxide and a new lipid radical, which causes the continuation and acceleration of the chain reaction. In fatty foods, lipid peroxidation is the main cause of loss of quality [6]. In the human body, excessive production of free radicals can cause destructive and lethal cellular effects by oxidizing lipids, proteins, DNA, and enzymes. In fact, the generation of reactive oxygen species has been related to heart diseases, stroke, arteriosclerosis, diabetes mellitus, cancer, and neurodegenerative and inflammatory diseases $[7,8,9,10]$. Antioxidants can protect foods and human body against deterioration by ROS, retarding the progress of many chronic diseases. Although many synthetic antioxidants as butylatedhydroxytoluene (BHT), butylatedhydroxyanisole (BHA), tert-butylhydroquinone (TBHQ), and propyl gallate are used for food and pharmaceutical industries to retard peroxidation processes, the substitution of these synthetic antioxidant by natural ones is gaining interest due to health concerns and consumer's preferences $[11,12]$. Therefore, the use of natural antioxidant peptides derived from food sources could be of interest for food industry. Due to the enormous volume of fish processing waste generated annually, a great deal of attention has been paid in the obtaining of antioxidant peptides from collagenous sources. These antioxidant peptides derived from collagen may exert higher antioxidant effect than others derived from other protein sources [13-15]. Hydrolysates exhibiting antioxidant activity have been obtained from collagen or gelatine of different marine sources, as Alaska Pollack skin [16], hoki fish skin [15], cobia skin [17, 18], brown-stripe red snapper skin [19], tuna backbones [20], sole skin [21], jellyfish umbrella [22], cod [23], or squid skin [15, 21, 24-27]. Some collagen/gelatine-derived antioxidant peptides have been further purified and sequenced (Table 1). 
Table 1 Antioxidant peptides derived from marine collagenous sources

\begin{tabular}{|c|c|c|c|c|}
\hline Source & Sequence & Enzyme & Activity & Ref. \\
\hline $\begin{array}{l}\text { Alaska Pollack skin gelatine } \\
\text { (Theragra chalcogramma) }\end{array}$ & $\begin{array}{l}\text { Gly-Glu-Hyp-Gly-Pro-Hyp-Gly-Pro-Hyp- } \\
\text { Gly-Pro-Hyp-Gly-Pro-Hyp-Gly } \\
\text { Gly-Pro-Hyp-Gly-Pro-Hyp-Gly-Pro-Hyp- } \\
\text { Gly-Pro-Hyp-Gly }\end{array}$ & $\begin{array}{l}\text { Alcalase, } \\
\text { Pronase E } \\
\text { Collagenase }\end{array}$ & $\begin{array}{l}\text { Inhibition of lipid peroxidation } \\
\text { Increase of cell viability exposed to t-BHP }\end{array}$ & [16] \\
\hline $\begin{array}{l}\text { Hoki skin gelatine } \\
\text { (Jonius belengerii) }\end{array}$ & His-Gly-Pro-Leu-Gly-Pro-Leu & Trypsin & $\begin{array}{l}\text { Radical scavenging } \\
\text { Inhibition of lipid peroxidation } \\
\text { Increase of antioxidative enzyme levels in hepatoma cell }\end{array}$ & [15] \\
\hline $\begin{array}{l}\text { Squid skin gelatine } \\
\text { (Dosidicus gigas) }\end{array}$ & $\begin{array}{l}\text { Phe-Asp-Ser-Gly-Pro-Ala-Gly-Val-Leu } \\
\text { Asn-Gly-Pro-Leu-Gln-Ala-Gly-Gln-Pro-Gly-Glu-Arg }\end{array}$ & Trypsin & $\begin{array}{l}\text { Radical scavenging } \\
\text { Increase of cell viability exposed to t-BHP }\end{array}$ & [27] \\
\hline Tuna backbone & $\begin{array}{l}\text { Val-Lys-Ala-Gly-Phe-Ala-Trp-Thr- } \\
\text { Ala-Asn-Gln-Gln-Leu-Ser }\end{array}$ & Pepsin & $\begin{array}{l}\text { Radical scavenging } \\
\text { Inhibition of lipid peroxidation }\end{array}$ & {$[20]$} \\
\hline $\begin{array}{l}\text { Squid tunic gelatine } \\
\text { (Dosidicus gigas) }\end{array}$ & $\begin{array}{l}\text { Gly-Pro-Leu-Gly-Leu-Leu-Gly-Phe-Leu- } \\
\text { Gly-Pro-Leu-Gly-Leu-Ser }\end{array}$ & Alcalase & $\begin{array}{l}\text { Radical scavenging } \\
\text { Ferric reducing power }\end{array}$ & {$[25]$} \\
\hline $\begin{array}{l}\text { Nile Tilapia gelatine } \\
\text { (Oreochromis niloticus) }\end{array}$ & Asp-Pro-Ala-Leu-Ala-Thr-Glu-Pro-Asp-Pro-Met-Pro-Phe & Alcalase & $\begin{array}{l}\text { Protective effect against free radical-induced cellular and } \\
\text { DNA damage in murine microglial cell }\end{array}$ & [61] \\
\hline $\begin{array}{l}\text { Pacific cod skin gelatine } \\
\text { (Gadus macrocephalus) }\end{array}$ & $\begin{array}{l}\text { Thr-Cys-Ser-Pro } \\
\text { Thr-Gly-Gly-Gly-Asn-Val }\end{array}$ & Papain & $\begin{array}{l}\text { Radical scavenging } \\
\text { Protective effect against oxidation-induced } \\
\text { DNA damage in mouse macrophages cell }\end{array}$ & [26] \\
\hline $\begin{array}{l}\text { Pacific cod skin gelatine } \\
\text { (Gadus macrocephalus) }\end{array}$ & Leu-Leu-Met-Leu-Asp-Asn-Asp-Leu-Pro-Pro & $\begin{array}{l}\text { Pepsin, } \\
\text { Trypsin } \\
\alpha-C h y m o t r y p s i n\end{array}$ & $\begin{array}{l}\text { Radical scavenging } \\
\text { Protective effect against oxidation of membrane lipids, } \\
\text { proteins and nuclear DNA in mouse monocyte cells }\end{array}$ & [23] \\
\hline
\end{tabular}


The antioxidant effect of some collagen-derived peptides has been observed in culture cells. For example, peptides isolated from cod skin gelatine may protect living cells against free radical mediated oxidative damage $[23,26]$. Two potent antioxidant peptides derived from jumbo squid skin gelatine may exert a protective effect in human lung fibroblasts against radical-mediated oxidation [27]. Kim et al. [16] have also reported the ability of two antioxidant peptides isolated from fish skin gelatine hydrolysate to enhance cell viability in cultured liver cells [16]. The protective effect of peptides against free radical mediated oxidative damage could be ascribed to their ability to enhance the expression of antioxidant enzymes, as observed in cultured human hepatoma cells [15].

The exact mechanism by which some peptides display antioxidant activity is not fully understood. Various hypotheses have been put forward to explain this activity. Some researchers agree that the antioxidant activity of protein hydrolysates cannot be attributable to a single antioxidant mechanism. Thus, some peptides derived from hydrolysed proteins would exert antioxidant activities by acting like free radical scavengers, lipid peroxidation inhibitors and/or chelating agents [28, 29]. The radicalscavenging activity of some peptides could be ascribed to the presence of determined amino acids within their sequence which could donate protons to electron-deficient radicals [30]. Dávalos et al. [31] have evaluated the antioxidant activity of individual amino acids and have observed that Trp, Tyr and Met exhibit the highest antioxidant activity, followed by Cys, His and Phe. The remaining amino acids (Arg, Asn, Gln, Asp, Pro, Ala, Val, Lys, Ile, Thr, Leu, Glu, and Gly) do not exhibit apparent antioxidant activity. The antioxidant activity of His could be ascribed to the proton-donation ability of the imidazole group, while that of Cys could be related to the possible interactions of the sulfhydryl group with free radicals [32]. However, many peptides with demonstrated antioxidant capacity do not contain any of the above mentioned antioxidant amino acids in their sequence. It leads to think that other factors must also influence in the antioxidant activity of the peptides. For example, the antioxidant capacity could be affected by the peptide conformation, abundance and also the position of certain amino acids within the peptide sequence [33]. In this sense, the high Gly and Pro content in collagen could be related to the antioxidant activity of some collagen-derived peptides. The presence of several residues of Gly in a peptide sequence may confer high flexibility on the peptide structure, while the pyrrolidine ring of Pro could impose certain conformational constraints in the secondary structure of the peptide. Kim et al. [16] have isolated two antioxidant peptides from a hydrolysate of Alaska Pollack skin, both containing a Gly 
residue at the C-terminus and the repeating motif Gly-Pro-Hyp (Table 1). The gelatine-derived peptide Asn-Gly-Pro-Leu-Gln-Ala-Gly-Gln-Pro-Gly-Glu-Arg also comprises several Gly residues and has been found to exhibit valuable free radical quenching capacity [27].

The high content of hydrophobic amino acids could also affect the antioxidant activity of the peptides [27]. The hydrophobic nature of the peptides would enhance their solubility in lipids and hence the access to hydrophobic radical species and polyunsaturated fatty acids [16, 34, 35]. However, Alemán et al. [36] have not observed any relation between the hydrophobic amino acid content and the antioxidant properties of several marine skin gelatines. Mendis et al. [27] have suggested that the antioxidant activity of squid skin gelatine could be due to hydrophilic and hydrophobic partitioning in the peptide sequence. The molecular weight of the peptides is also believed to play a key role in their antioxidant activity. Alemán et al. [25] have observed an inverse relationship between antioxidant capacity and molecular weight in a fractionated squid skin hydrolysate, although the highest antioxidant activity was not found in the lowermost molecular weight fraction. This fact was ascribed to the presence, in that fraction, of a large number of free amino acids with reduced antioxidant potency. Other authors [17, 37] have also found low molecular weight antioxidant peptides $(<1 \mathrm{kDa})$ in marine gelatine hydrolysates.

\section{Antihypertensive activity}

Hypertension represents one of the major independent risk factors for myocardial infarction, congestive heart failure, arteriosclerosis, stroke, and end-stage renal disease [38]. In fact, hypertension is a worldwide problem of epidemic proportions that affects over $25 \%$ of the adults' population. AngiotensinI converting enzyme (ACE) plays an important role in the regulation of blood pressure and hypertension [39]. For that reason, ACE inhibition has become the main target in treatment of hypertension. Captopril, Lisinopril and Enalapril are some examples for drugs targeted as ACE inhibitors. However, the adverse side effects of synthetic drugs have increased the search for natural ACE-inhibitory peptides [40, 41]. Some collagen and gelatine hydrolysates have shown potential to be used as mild or moderate ACE inhibitors. Table 2 shows the sequence of several ACE-inhibitory peptides isolated and identified in gelatine hydrolysates derived from fish skins [13, 42, 43], scales [23, 44], chum salmon cartilage [42], sea cucumbers [45] and squid tunics $[25,46,47]$. 
Table 2: ACE-inhibitory peptides derived from marine collagenous sources. The potency of these collagen-derived peptides to inhibit $\mathrm{ACE}_{\text {activity is }}$ expressed as an $\mathrm{IC}_{50}$ value, which is the ACE inhibitor concentration leading to $50 \%$ inhibition of ACE activity.

\begin{tabular}{|c|c|c|c|c|}
\hline Source & Sequence & Enzyme & Activity $\left(\mathrm{IC}_{50}\right)$ & Ref. \\
\hline $\begin{array}{l}\text { Alaska Pollack skin gelatine } \\
\text { (Theragra chalcogramma) }\end{array}$ & $\begin{array}{l}\text { Gly-Pro-Leu } \\
\text { Gly-Pro-Met }\end{array}$ & $\begin{array}{l}\text { Alcalase, } \\
\text { Pronase E } \\
\text { collagenase }\end{array}$ & $\begin{array}{l}\mathrm{IC}_{50} 2.6 \mu \mathrm{M} \\
\mathrm{IC}_{50} 17.13 \mu \mathrm{M}\end{array}$ & [13] \\
\hline $\begin{array}{l}\text { Squid tunic gelatine } \\
\text { (Dosidicus gigas) }\end{array}$ & $\begin{array}{l}\text { Gly-Pro-Leu-Gly-Leu-Leu-Gly-Phe-Leu- } \\
\text { Gly-Pro-Leu-Gly-Leu-Ser }\end{array}$ & Alcalase & $\mathrm{IC}_{50} 90.03 \mu \mathrm{M}$ & [25] \\
\hline $\begin{array}{l}\text { Nile Tilapia gelatine } \\
\text { (Oreochromis niloticus) }\end{array}$ & $\begin{array}{l}\text { Asp-Pro-Ala-Leu-Ala-Thr-Glu-Pro-Asp-Pro-Met-Pro- } \\
\text { Phe }\end{array}$ & Alcalase & $\mathrm{IC}_{50} 62.2 \mu \mathrm{M}$ & [61] \\
\hline $\begin{array}{l}\text { Pacific cod skin gelatine } \\
\text { (Gadus macrocephalus) }\end{array}$ & $\begin{array}{l}\text { Thr-Cys-Ser-Pro } \\
\text { Thr-Gly-Gly-Gly-Asn-Val }\end{array}$ & Papain & $\begin{array}{l}81 \% \text { of } \mathrm{ACE} \text { inhibition } \\
\text { at } 0.5 \mathrm{mg} / \mathrm{mL}\end{array}$ & [26] \\
\hline $\begin{array}{l}\text { Pacific cod skin gelatine } \\
\text { (Gadus macrocephalus) }\end{array}$ & Leu-Leu-Met-Leu-Asp-Asn-Asp-Leu-Pro-Pro & $\begin{array}{l}\text { Pepsin, } \\
\text { Trypsin } \\
\alpha-\text { Chymotrypsin }\end{array}$ & $\mathrm{IC}_{50} 35.7 \mu \mathrm{M}$ & [23] \\
\hline
\end{tabular}


The structure-activity relationship of food derived ACE-inhibitory peptides has not yet been fully established. The ACE-inhibitory activity of gelatine-derived peptides could be ascribed to their Cterminal sequence. Ondetti and Cushman [48] have observed that ACE-inhibitory peptides seem to compete with biologically important ACE substrates by interaction of their C-terminal tripeptide residues with subsites at the active-site of the enzyme. Other authors [39, 49] have highlighted the important effect on the affinity of ACE-competitive inhibitors to ACE of hydrophobic amino acid residues (aromatic or branched side chains) located at the three C-terminal positions. The presence of $\mathrm{C}$ - terminal amino acids with a positive charge on the $\varepsilon$-amino group (e.g., Arg and Lys) may also contribute to the ACEinhibitory potency $[49,50,51]$. The high content of Pro residues within the sequence of ACE-inhibitory peptides has also been linked to the ACE-inhibitory potency $[52,53]$. Indeed, the synthetic ACE-inhibitor Captopril is a sulfhydryl-containing analogue of Pro, whereas Enalapril is a derivative of Ala and Pro. The molecular weight of the peptides has also been found to influence on the ACE inhibitory activity. In particular, the ACE-inhibitory peptides are generally very short and have low-molecular weight [13, 25, $45,54,55]$. Nonetheless, some ACE-inhibitory peptides of 9-10 amino acids long have recently been found in gelatine-derived hydrolysates (Table 2).

The high concentration of both hydrophobic amino acids and Pro residues in collagen suggests that this protein could be a good source of ACE-inhibitory peptides [56, 57]. Indeed, gelatine peptides exhibiting ACE-inhibitory activity in vitro and also in vivo have been widely described. Oral administration of protein hydrolysates derived from sea bream scales and salmon skins may successfully decrease blood pressure in spontaneously hypertensive rats $[44,58]$. As well, the oral administration of the most active ACE-inhibitory fractions of gelatine hydrolysates derived from either sea cucumber, jellyfish or squid has significantly reduced blood pressure in renal hypertensive rats [45, 47, 59]. The dipeptide Gly-Pro has also induced an antihypertensive effect in SHR [54]. However, there is a lack of information on the effect of gelatine-derived peptides on hypertensive patients.

Finally, it is worth mentioning that antioxidant peptides may also have ACE-inhibitory activities in vitro [60]. Multifunctional gelatine-derived peptides exerting both ACE-inhibitory and antioxidant activities have been found in hydrolysates of squid skin $[25,36]$, Pacific cod skin $[23,26]$, Nile tilapia [61] and cartilage and skin of chum salmon [42]. 


\section{Antimicrobial activity}

Bioactive peptides exerting antimicrobial properties have interesting applications in the current context of food safety and food protection by means of natural products. Although potent antimicrobial compounds are nowadays available, antimicrobial peptides show the advantage of being able to kill target cells rapidly. Moreover, antimicrobial peptides have a broad spectrum of activity, including activity for some of the more serious antibiotic-resistant pathogens in clinics.

Antimicrobial peptides are mostly small cationic peptides, and are observed throughout nature. They have been isolated from most animals including insects and other invertebrates, amphibians, birds and mammals. Most of the antimicrobial peptides that are a benefit to health are synthesized by the cells of the organism itself [62-64]. In mammals, they are found both at the epithelial surfaces and within granular phagocytic cells. In addition to their known antimicrobial role, mammalian cationic peptides are also an extremely important player in mediating innate immune responses to infection [65-67].

Cationic antimicrobial peptides are short (usually less than 50 amino acids) and usually possess excess positively charged Lys and/or Arg or His residues (the latter being charged at acidic pH only) and a large percentage (around 50\%) of hydrophobic amino acids. To this date, more than 750 antimicrobial peptides have been reported [63] and exhibit very little sequence similarity. The molecular mechanisms of action of cationic antimicrobial peptides are not fully understood. Upon interaction with bacterial membranes, cationic peptides generally adopt a strongly amphipathic or amphiphilic three-dimensional structure. This ability to adopt an amphipathic structure is what allows cationic peptides to insert into biological membranes and form channels, with specificity for prokaryotic cell membranes. The differences in membrane composition between Gram-positive and Gram-negative bacteria may therefore have implications for the mode of action and bacterial specificity of these antibacterial compounds [68]. Other mechanisms for microbial killing have been reported. Thus, some antimicrobial peptides could inhibit the synthesis of the bacterial cell wall and/or the nucleic-acid, stimulate its autolytic enzyme system, or act synergistically with other host innate immune molecules [69-73].

Antimicrobial peptides can be obtained during gastrointestinal digestion of food protein molecules [7476]. Antimicrobial peptides have been found in hydrolysates of milk casein, $\alpha$-lactalbumin, $\beta$ lactoglobulin, ovalbumin and serum albumin [77]. However, there is not enough information on the antimicrobial properties of collagen or gelatine-derived peptides. Theoretically, they could exert 
interesting antibacterial activity, as some linear antimicrobial peptides identified have a high proportion of select residues, particularly Pro, Arg, or Gly, which are abundant in collagen [63]. Gómez-Guillén et al. [37] have recently obtained antimicrobial tuna and squid skin hydrolysates. These gelatine hydrolysates were highly active against different strains of Gram-positive and Gram-negative bacteria, mainly Lactobacillus acidophilus and Bifidobacterium animalis subp. Lactis, Shewanella putrefaciens and Photobacterium phosphoreum. Fractions from tuna hydrolysate seemed to be more active than squid ones for Lactobacillus acidophilus, Pseudomona aeruginosa and Salmonella choleraesuis; whereas squid fractions were more effective at inhibiting the growth of Aeromona hydrophila. The best antimicrobial ability was mainly found in the lowermost molecular weight fractions, especially in squid samples. Peptides from fish gelatine have a repeated motif of Gly-Pro-Ala triplets in their structure [56], and this hydrophobic character would let peptides enter the membrane, as the positive charge would initiate the peptide interaction with the negatively charged bacteria surface [78] and consequently the pore formation.

\section{Role in bone and joint disease}

Osteoarthritis and osteoporosis are two of the most common musculoskeletal disorders. Treatment of osteoarthritis includes analgesics and anti-inflammatory agents, lubricating, cushioning agents and nutritional supplements. Treatment for osteoporosis includes oestrogenic hormone replacement, bisphosphonates, calcitonin, selective oestrogen receptor agonists, fluorides, and parathormone derivatives. Nonetheless, therapeutic responses are limited in many patients and it could be considered that the best treatment for osteoarthritis and osteoporosis has not been discovered yet. Advances in treatment of osteoarthritis and osteoporosis include new and safer compounds (e.g., glucosamine, chondroitin sulphate, or methyl-sulfonyl-methane) capable of repairing damaged articular cartilage or at least decelerating its progressive degradation [79]. In this sense, collagen hydrolysates are safer compounds that could provide, with less overall toxicity, a greater symptomatic relief than pharmaceutical drugs.

Osteoarthritis is a joint disease characterized by progressive destruction of joint cartilage and its associated structures (bone, synovial and fibrous joint capsules), and also of the periarticular musculature. This disorder is basically produced by an imbalance between the synthesis and degradation of the articular cartilage. This imbalance leads to the classic pathologic changes of wearing away and destruction of cartilage. Although the beneficial effect of collagen hydrolysates on joint pain is known 
from the Middle Age, scientific evidences on the effective management of osteoarthritis with collagen hydrolysates have recently been reported $[5,80,81]$. In clinical studies with patients suffering joint disease, gelatine hydrolysates seemed to exert a direct effect on cartilage [5]. The mechanism by which gelatine hydrolysates stimulate cartilage metabolism is unknown. Articular cartilage is comprised of chondrocytes and extracellular matrix, being this maintained by chondrocytes [82]. The matrix consists of tissue fluid and a framework of structural macromolecules synthesized by the chondrocytes. These macromolecules are mainly type II collagen, proteoglycans and non-collagenous proteins. Experimental studies have suggested that some gelatine-derived peptides orally administered are absorbed intact in the intestine. Subsequently, these peptides would accumulate preferably in cartilage, where finally may stimulate cartilage metabolism [81]. Some evidences exist on the ability of collagen hydrolysates to stimulate biosynthesis of type II collagen and proteoglycans in chondrocytes [83]. Raabe et al. [84] have reported the marked effect of a fish collagen hydrolysate on chondrogenic differentiation of equine adipose tissue-derived stromal cells. These studies suggest that effectiveness of collagen hydrolysates on biosynthesis of macromolecules would be based on their unique amino acid composition, very similar to that of type II collagen. Oral administration of collagen hydrolysates would provide high levels of Gly and Pro, two amino acids essentials for the stability and regeneration of cartilage [85]. The therapeutic effect of collagen hydrolysates on osteoarthritis could also be mediated by the effect of specific peptides on gene expression and function of chondrocytes. In animal studies, Nakatani et al. [86] have observed that the peptide Pro-Hyp is able to reduce alkaline phosphatase activity in chondrocytes, and also inhibits the differentiation of these cells into mineralised chondrocytes. The effect of bioactive peptides on chondrocytes metabolism could be mediated by interaction with specific receptors on cell membranes [86]. Nonetheless, this fact has received relatively little attention.

Osteoporosis is a metabolic disorder in which the bones become increasingly porous, brittle, and subject to fracture, owing to loss of calcium and other mineral components. Osteoporosis results in pain, bone fragility, and increased susceptibility to fracture. The exact cause of bone loss in patients with osteoporosis is not yet clear. Theoretically, increased activity of osteoclasts, decreased activity of bone forming osteoblasts, or both may be associated with osteoporosis. Recent animal studies have suggested a positive role of collagen hydrolysates on osteoporosis. Hydrolysed collagen-enriched diet may improve bone collagen metabolism and bone mineral density in rats and mice fed a calcium- or protein-deficient diet $[87,88]$. Similarly, oral administration of collagen hydrolysate from shark skin has increased 
production of newly synthesized type I collagen and proteoglycan in the bone matrix of ovariectomized rats [89]. Guillerminet et al. [90] administered a diet enriched with a collagen hydrolysate to ovariectomized mice during 12 weeks, and observed that osteoblast activity was increased at the end of the experiment, while differentiation and maturation of osteoclasts was lowered. These effects on osteoblasts and osteoclasts led to a significant stimulation of bone formation and mineralization. Likewise, other studies have found that cod bone gelatine may prevent bone loss by decreasing bone resorption in ovariectomized rats [91]. The effect of collagen proteins on osteoporosis has also been investigated in patients with osteoporosis. A diet rich in collagen proteins may enhance and prolong the therapeutic effect of calcitonin on osteoporosis in postmenopausal women [92]. Nevertheless, oral administration of collagen proteins in absence of calcitonin has not produced any effect on bone metabolism in postmenopausal women with low bone mineral density [93].

The mechanism by which oral administration of hydrolysed collagen may improve bone formation in rats remain unclear, but has been suspected to be associated with the release and absorption of collagenderived peptides acting on bone metabolism, as observed in cartilage [81]. This effect could also be mediated by interaction of small collagen-derived peptides with the bone matrix. In this sense, the type I collagen-derived peptide Asp-Gly-Glu-Ala may bind to $\alpha_{2} \beta_{1}$ integrin receptors on cell membranes and stimulate osteoblast-related gene expression of bone marrow cells [94]. The biological effect of collagenderived peptides on bone remodelling could also be mediated by their binding to calcitonin or CGRP receptors on cell membranes. Nonetheless, this fact has been little studied. Further research must be necessary to elucidate how the collagen hydrolysates may exert a therapeutic effect on patients with osteoporosis.

\section{Opioid-like activity}

Glyproline peptides have exhibited interesting opioid-like effects in animals. Glyproline family includes simple Pro-containing peptides widely found in gelatine and collagen hydrolysates: Pro-Gly (PG), GlyPro (GP), Pro-Gly-Pro (PGP), Hyp-Gly, Gly-Hyp. Some of these peptides could cross the blood brain barrier and directly affect central nervous structures involved in organism's response to stress factors [95, 96]. Several experiments have shown that PGP and GP may correct stress-induced impairments in behaviour of rats [96-98]. Glyproline peptides may also potentiate memory consolidation processes in the central nervous system [99]. Furthermore, interesting in vivo effects of glyproline peptides on pain 
sensitivity have been reported. In particular, GP may suppress the analgesic action of morphine [100], and PGP, PG and PG may diminish visceral pain sensitivity in rats in a dose related manner [98].

\section{Calciotropic activity (CGRP-like molecules)}

CGRP (Calcitonin Gene Related Peptide) is a potent vasodilator neuropeptide in humans [101]. CGRP also plays an important role in the modulation of many other physiological functions. Additional biological functions mediated by CGRP include: regulation of pituitary hormone secretion, release of pancreatic enzymes, control of gastric acid secretion, thermoregulation, decrease in food intake, bone remodelling, and prevention of complication during pregnancy $[102,103]$. In the last years, different CGRP-like peptides have been found in hydrolysates derived from marine collagenous sources (Table 3).

The CGRP-like peptides are molecules that show an affinity for CGRP-receptors on cell membranes and either positively or negatively affect the activity of the receptor. 
Table 3: Concentration of CGRP- and gastrin/CCK-like molecules in different protein hydrolysates derived from marine collagen. ED50 for gastrin/CCK-like molecules gives information on the quantity of sample that induces a $50 \%$ inhibition of the initial binding of CCK to its specific antibody. ED50 for CGRP-like molecules gives information on the quantity of sample that induces a $50 \%$ inhibition of the initial binding of human CGRP to specific receptors on rat liver membranes.

\begin{tabular}{l|ccr}
\hline Gastrin/CCK-like molecules & [Gastrin/CCK-like molecules], pg/mg dry weight ED50 (mg dry weight) Ref. \\
\hline Cod backbones & $0.5-1.6$ & $2.17-9.65$ & {$[105]$} \\
North Atlantic lean fish skin & 1.3 & 11.03 & {$[106]$} \\
Sardine heads & $\approx 1.1-9.0$ & ND & {$[107]$} \\
\hline CGRP-like molecules & [CGRP-like molecules], pg/mg dry weight & ED50 (mg dry weight) Ref. \\
\hline Cod backbones & $9.09-66.24$ & $1-6.85$ & {$[105]$} \\
North Atlantic lean fish skin & 4 & 19 & {$[106]$} \\
& [CGRP-like molecules], pg/mg protein & ED50 (pg protein) & \\
Siki heads & 75 & 4100 & {$[104]$} \\
Sardine heads & ND & $\approx 50-800$ & {$[107]$} \\
Sardine heads & 0.14 & 311 & {$[108]$} \\
\hline
\end{tabular}

Martínez-Alvarez et al. [104] have reported the occurrence of CGRP-like molecules in an industrial protein hydrolysate from siki heads. These CGRP-like molecules showed agonistic activity, as they stimulated production of cAMP. This effect was reversed by the presence of the specific antagonist $\mathrm{CGRP}_{8-37}$. The sequence of the siki-derived CGRP-like molecules was found to be Gly-Phe-Pro*-GlyPro-Glu-Gly-Leu, where the third residue (Pro*) could also match with Hyp. This sequence shows high homology to fragments of collagen from different species.

The occurrence of CGRP-like molecules in other collagen hydrolysates has also been reported. CGRPlike molecules have been found in protein hydrolysates derived from cod backbones [105]. The content of CGRP-like molecules was dependent on the time of hydrolysis and also on the quality of the raw material used. The molecular weight of the CGRP-like molecules found in the hydrolysates of cod backbones was 
estimated at 3300 and 2350 Da. Moreover, Picot et al. [106] have reported the occurrence of CGRP-like molecules in a commercial hydrolysate from skins of North Atlantic lean fish. Ravallec-Ple et al. [107] and Rousseau et al. [108] have also reported the presence of interesting CGRP-like molecules in protein hydrolysates derived from sardine heads. These molecules were able to bind to specific CGRP receptors on rat liver membranes and exhibited antagonistic effect [108], unlike the CGRP-like molecules from the siki heads hydrolysate [104].

\section{Secretagogue activity (gastrin/CCK-like molecules)}

Gastrin and cholecystokinin (CCK) are small intestinal hormones belonging to the secretagogue family. Gastrin is a gastric hormone that stimulates postprandial gastric acid secretion and epithelial cell proliferation [109]. In humans, gastrin is primarily found in two forms: one form with 17 amino acids in the sequence (little gastrin 1), and other with 34 residues in the sequence (big gastrin). Cholecystokinin is a family of peptide hormones that control the emptying of the gallbladder and pancreatic enzyme secretion. CCK also mediates other physiological processes: it regulates intestinal motility, satiety signalling and also the inhibition of gastric acid secretion [110]. Both gastrin and CCK share the common sequence for gastrin and CCK (-Trp-Met-Asp-Phe- $\mathrm{NH}_{2}$ ).

The occurrence of molecules with capacity to interact with specific gastrin antibodies (gastrin/CCK-like molecules) in protein hydrolysates derived from collagenous sources has been reported (Table 3). Gastrin/CCK-like molecules have been found in protein hydrolysates derived from sardine heads [107, 108, 111], cod heads [111], cod backbones [105], siki heads [112] and skins from North Atlantic lean fish [106]. The hydrolysis time and the quality of the raw material had a strong influence in the amount of the gastrin/CCK-like molecules found in the hydrolysates [105, 107, 108]. Although the in vivo effect of the gastrin/CCK-like molecules on satiety has been scarcely investigated, they could be interesting satietyingredients with promising applications in functional foods.

\section{Other interesting activities}

Collagen-derived peptides could also exhibit other interesting physiological activities. Glyproline peptides are abundant in collagen and gelatine hydrolysates and cause significant inhibition of some factors involved in blood coagulation and platelet aggregation [99, 113]. Some collagen-derived peptides may also suppress thrombocyte aggregation [114-116], as observed in vitro and also in vivo. The peptides 
PGP, PG, GP, and Gly-Pro-Gly-Gly have been found to show ability to increase fibrinolytic, anticoagulant, and antithrombotic activities in rat plasma [99, 113]. Furthermore, the protective antiulcer effect of Pro-Gly, Gly-Pro and Pro-Gly-Pro has been reported by different authors [117, 118]. The neuroprotective effect of glyprolines has also been reported [119], as well as their capacity to increase the resistance of gastric mucosa to damaging agents [98]. Glyprolines could also induce inhibition of mast cell degranulation [120] and potentiate chemotaxis-induced superoxide formation [121]. Other peptides (Pro-Hyp-Gly, Pro-Hyp and analogues) may also display chemotactic activity to fibroblasts, peripheral blood neutrophils and monocytes [122, 123]. Collagen hydrolysates could also enhance wound healing, as observed after ingestion of a Chum salmon skin hydrolysate [124]. Moreover, marine collagen peptides might improve glucose and lipid metabolism and help to control hyperglycaemia in patients with type 2 diabetes mellitus [125].

\section{Effect of gastrointestinal digestion on collagen-derived peptides}

Protein orally administered is enzymatically digested to their amino acid components in the gastrointestinal tract. Nonetheless, in vitro and in vivo studies have demonstrated that some collagen-derived peptides survive the gastrointestinal digestion [5]. These collagen-derived peptides could also pass across the intestinal barrier and reach a maximal plasma concentration in 6 hours [81]. The percentage of high molecular weight peptides (1-10 kDa) absorbed following oral administration of collagen hydrolysate could reach $10 \%$, with some individual variability [5]. The reason of this resistance to protein digestion of gelatine-derived peptides is the presence of Pro residues within their sequence. Di- or tripeptides, especially those with C-terminal Pro or Hyp residues, are generally resistant to degradation by gastric enzymes [50, 126]. Proline-containing oligopeptides are also particularly resistant to proteolysis in intestine and enterocytes, and this may result in their partial penetration into the bloodstream. In this sense, the presence of small Pro-containing oligopeptides in human blood after ingestion of hydrolysed collagen has been documented $[127,128]$. These peptides constituted Pro-Hyp primarily, as well as other di- or tripeptides in small portions (Pro-Pro, Ala-Hyp, Hyp-Pro-Hyp, Gly-Pro-Val, Ala-Hyp-Gly, ProHyp-Gly, Leu-Hyp, Ile-Hyp, and Phe-Hyp). The peptide Gly-Pro-Hyp is able to resist the effect of peptidases in blood and may remain in plasma of rats for several hours [129, 130]. As well, Pro-Hyp is not digested by peptidases and is excreted into urine without degradation [130, 131]. 


\section{Concluding remarks}

In summary, this review demonstrates that marine collagen may be an excellent source of molecules exhibiting interesting nutraceutical properties. The abundance of collagen in fish disposals, the resistance of some collagen-derived peptides to gastrointestinal digestion, and also their capacity to reach intact the bloodstream suggest that marine collagen could be an interesting source of bioactive peptides with promising applications in functional foods. Nonetheless, the presumptive health enhancing effect of collagen/gelatine-derived peptides has not been thoroughly demonstrated in vivo and deserve further investigation. Additional in vivo studies will be necessary before considering the application of gelatinederived peptides as dietary supplements in functional foods.

\section{Acknowledgements}

This work has been supported by The Spanish Agency for International Development Cooperation (AECID) under project AP/038291/11.

\section{References}

[1] Arnesen, J.A.; Gildberg, A. Extraction and characterisation of gelatine from Atlantic salmon (Salmo salar) skin. Bioresource Technology, 2007, 98(1), 53-57.

[2] Najafian, L.; Babji, A. S. A review of fish-derived antioxidant and antimicrobial peptides: Their production, assessment, and applications. Peptides, 2012, 33(1), 178-185.

[3] Stainsby, G. In: Advances in meat research, collagen as a food; Pearson, A.M., Dutson, T.R., Bailey A.J. Eds.; Van Nostrand Reinhold Company Inc: New York, 1987; Vol. 4, pp. 209-222.

[4] De Felice, S.L. The nutraceutical revolution: its impact on food industry R\&D. Trends in Food Science \& Technology, 1995, 6(2), 59-61.

[5] Moskowitz, R.W. Role of collagen hydrolysate in bone and joint disease. Seminars in Arthritis and Rheumatism, 2000, 30(2), 87-99.

[6] Di Bernardini, R.; Harnedy, P.; Bolton, D.; Kerry, J.; O’Neill, E.; Mullen, A.M.; Hayes, M. Antioxidant and antimicrobial peptidic hydrolysates from muscle protein sources and by-products. Food Chemistry, 2011, 124, 1296-1307. 
[7] Temple, N.J. Antioxidant and disease: More questions than answers. Nutrition Research, 2000, 20, 449-459.

[8] Butterfield, D.A.; Castegna, A.; Pocernich, C.B.; Drake, J.; Scapagnini, G.; Calabrese, V. Nutritional approaches to combat oxidative stress in Alzheimer's disease. Journal of Nutritional Biochemistry, 2002, $13,444-461$.

[9] Lee, J.; Koo, N.; Min, D.B. Reactive oxygen species, aging, and antioxidative nutraceuticals. Comprehensive Reviews in Food Science and Food Safety, 2004, 3, 21-33.

[10] Correa, P.; Fontham, E.; Bravo, L.E.; Mera, R. Antioxidant supplements for prevention of gastrointestinal cancers. Lancet, 2005, 3, 365-470.

[11] Hettiarachchy, N.S., Glenn, K.C., Gnanasambandan, R., Johnson, M.G. Natural antioxidant extract from fenugreek (Trigonella foenumgraecum) for ground beef patties. Journal of Food Science, 1996, 61, $516-519$.

[12] Park, P.J.; Jung, W.K.; Nam, K.S.; Shahidi, F.; Kim, S.K. Purification and characterization of antioxidative peptides from protein hydrolysate of lecithin-free egg yolk. Journal of the American Oil Chemists' Society, 2001, 78, 651-656.

[13] Byun, H.G.; Kim, S.K. Purification and characterization of angiotensin I converting enzyme (ACE) inhibitory peptides from Alaska Pollack (Theragra chalcogramma) skin. Process Biochemistry, 2001, 36, $1155-1162$

[14] Kim, S.K.; Kim, Y.T.; Byun, H.G.; Park, P.J.; Ito, H. Purification and characterization of antioxidative peptides from bovine skin. Journal of Biochemistry and Molecular Biology, 2001, 34, 214219.

[15] Mendis, E.; Rajapakse, N.; Kim, S.K. Antioxidant properties of a radical-scavenging peptide purified from enzymatically prepared fish skin gelatine hydrolysate. Journal of Agricultural and Food Chemistry, $2005,53,581-587$.

[16] Kim, S.K; Kim, Y.T; Byun, H.G; Nam, K.S; Joo, D.S; Shahidi, F. Isolation and characterization of antioxidative peptides from gelatine hydrolysate of Alaska. Journal of Agricultural and Food Chemistry, 2001, 49, 1984-1989. 
[17] Yang, J.I.; Ho, H.Y.; Chu, Y.J.; Chow, C.J. Characteristic and antioxidant activity of retorted gelatine hydrolysates from cobia (Rachycentron canadum) skin. Food Chemistry, 2008, 110, 128-136.

[18] Chow, C.J.; Yang, J.I. The effect of process variables for production of cobia (Rachycentron canadum) skin gelatine hydrolysates with antioxidant properties. Journal of Food Biochemistry, 2011, $35(3), 715-734$.

[19] Khantaphant, S.; Benjakul, S. Comparative study on the proteases from fish pyloric caeca and the use for production of gelatine hydrolysate with antioxidative activity. Comparative Biochemistry and Physiology, 2008, 151, 410-419.

[20] Je, J.; Qian, Z.; Byun, H.; Kim, S. Purification and characterization of an antioxidant peptide obtained from tuna backbone protein by enzymatic hydrolysis. Process Biochemistry, 2007, 42, 840-846.

[21] Giménez, B.; Alemán, A.; Montero, P.; Gómez-Guillén, M.C. Antioxidant and functional properties of gelatine hydrolysates obtained from skin of sole and squid. Food Chemistry, 2009, 114(3), 976-983.

[22] Zhuang, Y.L.; Sun, L.P.; Zhao, X.; Hou, H.; Li, B.F. Investigation of gelatine polypeptides of jellyfish (Rhopilema esculentum) for their antioxidant activity in vitro. Food Technology and Biotechnology, 2010, 48(2), 222-228.

[23] Himaya, S.W.A.; Ngo, D.H.; Ryu, B.; Kim, S.K. An active peptide purified from gastrointestinal enzyme hydrolysate of Pacific cod skin gelatine attenuates angiotensin-1 converting enzyme (ACE) activity and cellular oxidative stress. Food Chemistry, 2012, 132(4), 1872-1882.

[24] Lin, L.; Li, B. Radical scavenging properties of protein hydrolysates from Jumbo flying squid (Dosidicus eschrichitii Steenstrup) skin gelatine. Journal of the Science of Food and Agriculture, 2006, $86,2290-2295$.

[25] Alemán, A.; Giménez, B.; Pérez-Santín, E.; Gómez-Guillén, M.C.; Montero, P. Contribution of Leu and Hyp residues to antioxidant and ACE-inhibitory activities of peptides sequences isolated from squid gelatine hydrolysate. Food Chemistry, 2011, 125, 334-341. 
[26] Ngo, D.H.; Ryu, B.; Vo, T.S.; Himaya, S.W.A.; Wijesekara, I.; Kim, S.K. Free radical scavenging and angiotensin-I converting enzyme inhibitory peptides from Pacific cod (Gadus macrocephalus) skin gelatine. International Journal of Biological Macromolecules, 2011, 49(5), 1110-1116.

[27] Mendis, E.; Rajapakse, N.; Byun, H.G.; Kim, S.K. Investigation of jumbo squid (Dosidicus gigas) skin gelatin peptides for their in vitro antioxidant effects. Life Science, 2005, 77, 2166-2178.

[28] Erdmann, K.; Cheung, B.W.; Schroder, H. The possible roles of food-derived bioactive peptides in reducing the risk of cardiovascular disease. The Journal of Nutritional Biochemistry, 2008, 19(10), 643654.

[29] Sarmadi, B.H.; Ismail, A. Antioxidative peptides from food proteins: A review. Peptides, 2010, 31, 1949-1956.

[30] Suetsuna, K.; Ukeda, H.; Ochi, H. Isolation and characterization of free radical scavenging activities peptides derived from casein. Journal of Nutritional Biochemistry, 2000, 11, 128-131.

[31] Dávalos, A.; Miguel, M.; Bartolomé, B.; López-Fandiño, R. Antioxidant activity of peptides derived from egg white proteins by enzymatic hydrolysis. Journal of Food Protection, 2004, 67(9), 1939-1944.

[32] Qian, Z.; Jung, W.; Kim, S. Free radical scavenging activity of a novel antioxidative peptide purified from hydrolysate of bullfrog skin, Rana catesbeina Shaw. Bioresource Technology, 2008, 99, 1690-1698.

[33] Hernández-Ledesma, B.; Dávalos, A.; Bartolomé, B.; Amigo, L. Preparation of antioxidant enzymatic hydrolysates from $\alpha$-lactalbumin and $\beta$-lactoglobulin. Identification of active peptides by HPLC-MS/MS. Journal of Agricultural and Food Chemistry, 2005, 53, 588-593.

[34] Chen, H.M.; Muramoto, K.; Yamauchi, F. Structural analysis of antioxidative peptides from soybean $\beta$-conglycinin. Journal of Agriculture and Food Chemistry, 1995, 43, 574-578.

[35] Ranathunga, S.; Rajapakse, N.; Kim, S.K., Purification and characterization of antioxidative peptide derived from muscle of conger eel (Conger myriaster). European Food Research and Technology 2006, 222(3-4), 310-315.

[36] Alemán, A.; Giménez, B.; Montero, P.; Gómez-Guillén, M.C. Antioxidant activity of several marine skin gelatines. LWT- Food Science and Technology, 2011, 44, 407-413. 
[37] Gómez-Guillén, M.C.; López-Caballero, M.E.; López de Lacey, A.; Alemán, A.; Giménez, B.; Montero, P. In: Sea by-products as a real material: New ways of application; Le Bihan, E., Ed.; Transworld Research Network Signpost: Kerala (India), 2010; Chapter 7, pp. 89-115.

[38] Kearney, P.M.; Whelton, M.; Reynolds, K.; Muntner, P.; Whelton, P.K.; He, J. Global burden of hypertension. Lancet, 2005, 365, 217-223.

[39] Murray, B.A.; FitzGerald, R.J. Angiotensin converting enzyme inhibitory peptides derived from food proteins: Biochemistry, bioactivity and production. Current Pharmaceutical Design, 2007, 13(8), 773-791.

[40] Atkinson, A.B.; Robertson, J.I.S. Captopril in the treatment of clinical hypertension and cardiac failure. Lancet, 1979, 2(8147), 836-839.

[41] Messerli, F.H. Hypertension and sudden cardiac death. American Journal of Hypertension, 1999, 12 , 181-188.

[42] Nagai, T.; Nagashima, T.; Abe, A.; Suzuki, N. Antioxidative activities and angiotensin I-converting enzyme inhibition of extracts prepared from chum salmon (Oncorhynchus keta) cartilage and skin. International Journal of Food Properties, 2006, 9, 813-822.

[43] Park, C.H.; Kim, H.J.; Kang, K.T.; Park, J.W.; Kim, J.S. Fractionation and angiotensin I-converting enzyme (ACE) inhibitory activity of gelatine hydrolysates from by-products of Alaska Pollack surimi. Journal of Fisheries and Aquatic Sciences, 2009, 12, 79-85.

[44] Fahmi, A.; Morimura, S.; Guo, H. C.; Shigematsu, T.; Kida, K.; Uemura, Y. Production of angiotensin I converting enzyme inhibitory peptides from sea bream scales. Process Biochemistry, 2004, 39(10), 1195-1200.

[45] Zhao, Y.; Li, B.; Liu, Z.; Dong, S.; Zhao, X.; Zeng, M. Antihypertensive effect and purification of an ACE inhibitory peptide from sea cucumber gelatine hydrolysate. Process Biochemistry, 2007, 42, 15861591.

[46] Alemán, A.; Pérez-Santín, E.; Bordenave-Juchereau, S.; Arnaudin, I.; Gómez-Guillén, M. C.; Montero, P. Squid gelatine hydrolysates with antihypertensive, anticancer and antioxidant activity. Food Research International, 2011, 44(4), 1044-1051. 
[47] Lin, L.; Lv, S.; Li, B. Angiotensin-I-converting enzyme (ACE)-inhibitory and antihypertensive properties of squid skin gelatine hydrolysates. Food Chemistry, 2012, 131(1), 225-230

[48] Ondetti, M.A.; Cushman, D.W. Enzymes of the renin-angiotensin system and their inhibitors. Annual Review of Biochemistry, 1982, 51, 283-308.

[49] Cheung, H.S.; Wang, F.L.; Ondetti, M.A.; Sabo, E.F.; Cushman, D.W. Binding of peptide substrates and inhibitors of angiotensin-converting enzyme. Importance of the $\mathrm{COOH}$-terminal dipeptide sequence. Journal of Biological Chemistry, 1980, 255(2), 401-407.

[50] Vermeirssen, V.; Van Camp, J.; Verstraete, W., Bioavailability of angiotensin I converting enzyme inhibitory peptides. British Journal of Nutrition, 2004, 92(3), 357-366.

[51] Meisel, H.; FitzGerald, R.J. Biofunctional peptides from milk proteins: Mineral binding and cytomodulatory effects. Current Pharmaceutical Design, 2003, 9, 1289-1295.

[52] Meisel, H. Biochemical properties of bioactive peptides derived from milk proteins: Potential nutraceuticals for food and pharmaceutical applications. Livestock Production Science, 1997, 50(1-2), 125-138

[53] Contreras, M.; Carrón, R.; Montero, M.J.; Ramos, M.; Recio, I. Novel casein-derived peptides with antihypertensive activity. International Dairy Journal, 2009, 19, 566-573.

[54] Ichimura, T.; Yamanaka, A.; Otsuka, T.; Yamashita, E.; Maruyama, S. Antihypertensive effect of enzymatic hydrolysate of collagen and Gly-Pro in spontaneously hypertensive rats. Bioscience, Biotechnology and Biochemistry, 2009, 73, 2317-2319.

[55] Saiga, A.I.; iwai, K.; Hayakawa, T.; Takahata, Y.; Kitamura, S.; Nishimura, T.; Morimatsu, F. Angiotensin I-Converting Enzyme-Inhibitory Peptides Obtained from Chicken Collagen Hydrolysate. Journal of Agricultural and Food Chemistry, 2008, 56, 9586-9591.

[56] Kim, S.K.; Mendis, E. Bioactive compounds from marine processing byproducts - A review. Food Research International, 2006, 39(4), 383-393. 
[57] Gómez-Guillén, M.C.; Giménez, B.; López-Caballero, M.E.; Montero, M.P. Functional and bioactive properties of collagen and gelatine from alternative sources: A review. Food Hydrocolloids, $2011,25(8), 1813-1827$.

[58] Wang, L.; An, X.X.; Yang, F.M.; Xin, Z.H.; Zhao, L.Y.; Hu, Q.H. Isolation and characterisation of collagens from the skin, scale and bone of deep-sea redfish (Sebastes mentella). Food Chemistry, 2008, 108, 616-623.

[59] Zhuang, Y.; Sun, L.; Zhang, Y.; Liu, G. Antihypertensive effect of long-term oral administration of jellyfish (Rhopilema esculentum) collagen peptides on renovascular hypertension. Marine Drugs, 2012, 10(2), 417-426

[60] Hou, W.C.; Chen, H.J.; Lin, Y.H. Antioxidant peptides with angiotensin converting enzyme inhibitory activities and applications for angiotensin converting enzyme purification. Journal of Agricultural and Food Chemistry, 2003, 51, 1706-1709.

[61] Vo, T.S.; Ngo, D.H.; Kim, J.A.; Ryu, B.; Kim, S.K. An antihypertensive peptide from tilapia gelatin diminishes free radical formation in murine microglial cells. Journal of Agricultural and Food Chemistry, 2011, 59(22), 12193-12197.

[62] Zasloff, M. Antimicrobial peptides of multicellular organisms. Nature, 2002, 415, 389-395.

[63] Brogden, K.A.; Ackermann, M.; McCray, P.B.; Tack, B.F. Antimicrobial peptides in animals and their role in host defences. International Journal of Antimicrobial Agents, 2003, 22, 465-478.

[64] Sima, P.; Trebichavsky, I.; Sigler, K. Mammalian antibiotic peptides. Folia Microbiologica, 2003, 48, 123-137.

[65] Finlay, B.B.; Hancock, R.E. Can innate immunity be enhanced to treat microbial infections? Nature Reviews Microbiology, 2004, 2, 497-504.

[66] Boman, H.G. Peptide antibiotics and their role in innate immunity. Annual Reviews in Immunology, 1995, 13, 61-92. 
[67] McPhee, J.B., Scott, M.G.; Hancock, R.E. Design of host defence peptides for antimicrobial and immunity enhancing activities. Combinatorial Chemistry \& High Throughput Screening, 2005, 8, 257272.

[68] Floris, R.; Recio, I.; Berkhout, B.; Visser, S. Antibacterial and antiviral effects of milk proteins and derivatives thereof. Current Pharmaceutical Design, 2003, 9, 1257-1275.

[69] Ginsburg, I. Cationic peptides from leukocytes might kill bacteria by activating their autolytic enzymes causing bacteriolysis: why are publications proposing this concept never acknowledged (letter). Blood, 2001, 97, 2530-2531.

[70] Ginsburg, I. Bactericidal cationic peptides can also function as bacteriolysis-inducing agents mimicking beta-lactam antibiotics? it is enigmatic why this concept is consistently disregarded. Medical Hypotheses, 2004, 62, 367-374.

[71] Zhang, L.; Falla, T.J. Cationic antimicrobial peptides-an update. Expert Opinion in Investigational Drugs, 2004, 13, 97-106.

[72] Brogden, K.A. Antimicrobial peptides: pore formers or metabolic inhibitors in bacteria? Natural Reviews Microbiology, 2005, 3, 238-250

[73] Lohner, K.; Blondelle, S.E. Molecular mechanisms of membrane perturbation by antimicrobial peptides and the use of biophysical studies in the design of novel peptide antibiotics. Combinatorial Chemistry \& High Throughput Screening, 2005, 8, 241-256.

[74] Kitts, D.D.; Weiler, K. Bioactive proteins and peptides from food sources. Applications of bioprocesses used in isolation and recovery. Current Pharmaceutical Design, 2003, 9(16), 1309-1323.

[75] Korhonen, H.; Pihlanto, A. Food-derived bioactive peptides-Opportunities for designing future foods. Current Pharmaceutical Design, 2003, 9(16), 1297-1308.

[76] Pellegrini, A. Antimicrobial peptides from food proteins. Current Pharmaceutical Design, 2003, $9(16), 1225-1238$. 
[77] Biziulevicius, G.A. How food-borne peptides may give rise to their immunostimulatory activities: a look through the microbiologist's window into the immunologist's garden (hypothesis). British Journal of Nutrition, 2004, 92, 1009-1012.

[78] Wieprecht, T.; Dathe, M.; Epand, R.M.; Beyermann, M.; Krause, E.; Maloy, W.L.; McDonald, D.L.; Bienert, M. Influence of the angle subtended by the positively charged helix face on the membrane activity of amphipathic, antibacterial peptides. Biochemistry, 1997, 36, 12869-12880.

[79] Brief, A.A.; Maurer, S.G.; Di Cesare, P.E. Use of glucosamine and chondroitin sulfate in the management of osteoarthritis. Journal of the American Academic of Orthopaedic Surgeons, 2001, 9, 7178.

[80] Bello, A.E.; Oesser, S. Collagen hydrolysate for the treatment of osteoarthritis and other joint disorders: A review of the literature. Current Medical Research and Opinion, 2006, 22(11), 2221-2232.

[81] Oesser, S.; Adam, M.; Babel, W.; Seifert, J., Oral administration of (14)C labeled gelatine hydrolysate leads to an accumulation of radioactivity in cartilage of mice (C57/BL). Journal of Nutrition, 1999, 129(10), 1891-1895.

[82] Kuettner, K.E.; Aydelotte, M.B.; Thonar, E.J. Articular cartilage matrix and structure: a minireview. The Journal of Rheumatology.Supplement, 1991, 27, 46-48.

[83] Oesser, S.; Seifert, J. Stimulation of type II collagen biosynthesis and secretion in bovine chondrocytes cultured with degraded collagen. Cell Tissue Research, 2003, 311(3), 393-399.

[84] Raabe, O.; Reich, C.; Wenisch, S.; Hild, A.; Burg-Roderfeld, M.; Siebert, H.C.; Arnhold, S. Hydrolyzed fish collagen induced chondrogenic differentiation of equine adipose tissue-derived stromal cells. Histochemistry and Cell Biology, 2010, 134(6), 545-554.

[85] Walrand, S.; Chiotelli, E.; Noirt, F.; Mwewa, S.; Lassel, T. Consumption of a functional fermented milk containing collagen hydrolysate improves the concentration of collagen-specific amino acids in plasma. Journal of Agricultural and Food Chemistry, 2008, 56(17), 7790-7795. 
[86] Nakatani, S.; Mano, H.; Sampei, C.; Shimizu, J.; Wada, M. Chondroprotective effect of the bioactive peptide prolyl-hydroxyproline in mouse articular cartilage in vitro and in vivo. Osteoarthritis and Cartilage 2009, 17(12), 1620-1627.

[87] Koyama, Y.; Hirota, A.; Mori, H.; Takahara, H.; Kuwaba, K.; Kusubata, M.; Matsubara, Y.; Kasugai, S.; Itoh, M.; Irie, S. Ingestion of gelatine has differential effect on bone mineral density and body weight in protein undernutrition. Journal of Nutritional Science and Vitaminology, 2001, 47(1), 8486.

[88] Wu, J. Assessment of effectiveness of oral administration of collagen peptide on bone metabolism in growing and mature rats. Journal of bone and mineral metabolism, 2004, 22(6), 547-553.

[89] Nomura, Y.; Oohashi, K.; Watanabe, M.; Kasugai, S., Increase in bone mineral density through oral administration of shark gelatine to ovariectomized rats. Nutrition, 2005, 21(11-12), 1120-1126.

[90] Guillerminet, F.; Beaupied, H.; Fabien-Soulé, V.; Tomé, D.; Benhamou, C.L.; Roux, C.; Blais, A. Hydrolyzed collagen improves bone metabolism and biomechanical parameters in ovariectomized mice: An in vitro and in vivo study. Bone 2010, 46(3), 827-834.

[91] Han, X.; Xu, Y.; Wang, J.; Pei, X.; Yang, R.; Li, N.; Li, Y. Effects of cod bone gelatin on bone metabolism and bone microarchitecture in ovariectomized rats. Bone 2009, 44(5), 942-947.

[92] Adam, M.; Spacek, P.; Hulejova, H.; Galianova, A.; Blahos, J.; Postmenopausal osteoporosis. Treatment with calcitonin and a diet rich in cartilage proteins. Casopis Lekaru Ceskych, 1996, 135, 74-78.

[93] Cúneo, F.; Costa-Paiva, L.; Pinto-Neto, A.M.; Morais, S.S.; Amaya-Farfan, J. Effect of dietary supplementation with collagen hydrolysates on bone metabolism of postmenopausal women with low mineral density. Maturitas, 2010, 65(3), 253-257.

[94] Mizuno, M.; Kuboki, Y. Osteoblast-related gene expression of bone marrow cells during the osteoblastic differentiation induced by type I collagen. Journal of Biochemistry, 2001, 129(1), 133-138.

[95] Kopylova, G.N.; Bakaeva, Z.V.; Badmaeva, S.E.; Umarova, B.A.; Samonina, G.E.; Guseva, A.A. Therapeutic effects of glyprolines (PGP, GP, and PG) in rats with stress-induced behavioral disorders. Bulletin of Experimental Biology and Medicine, 2007, 143(2), 167-170. 
[96] Badmaeva, S. E.; Kopylova, G.N.; Abushinova, N.N.; Samonina, G. E.; Umarova, B. A., Effects of glyprolines on stress-induced behavioral disorders in rats. Neuroscience and Behavioral Physiology, 2006, 36(4), 409-413.

[97] Kopylova, G.N.; Badmaeva, S.E.; Levitskaya, N.G.; Samonina, G.E.; Umarova, B.A.; Guseva, A.A. Effect of Peptide Pro-Gly-Pro on Stress-Induced Behavioral Changes in Rats. Bulletin of Experimental Biology and Medicine, 2004, 138(1), 5-7.

[98] Samonina, G.; Lyapina, L.; Kopylova, G.; Pastorova, V.; Bakaeva, Z.; Jeliaznik, N.; Zuykova, S.; Ashmarin, I. Protection of gastric mucosal integrity by gelatine and simple proline-containing peptides. Pathophysiology, 2000, 7(1), 69-73.

[99] Ashmarin, I.P.; Karazeeva, E.P.; Lyapina, L.A.; Samonina, G. E., The simplest proline-containing peptides PG, GP, PGP, and GPGG: Regulatory activity and possible sources of biosynthesis. Biochemistry (Moscow), 1998, 63(2), 119-124.

[100] Ray, A.K.; Dey, P.K. In: Current Status of Centrally Acting Peptides. Dhawan, B.D., Ed.; Pergamon Press: Oxford, New York. 1982, pp. 261-264.

[101] Gupta, S.; Mehrotra, S.; Villalon, C. M.; Garrelds, I. M.; de Vries, R.; van Kats, J. P.; Sharma, H. S.; Saxena, P. R.; Maassenvandenbrink, A. Characterisation of CGRP receptors in human and porcine isolated coronary arteries: evidence for CGRP receptor heterogeneity. European Journal of Pharmacology, 2006, 530(1-2), 107-116.

[102] Arulmani, U.; MaassenVanDenBrink, A.; Villalon, C.M.; Saxena, P.R. Calcitonin gene-related peptide and its role in migraine pathophysiology. European Journal of Pharmacology, 2004, 500, 315330.

[103] Yallampalli, C.; Chauhan, M.; Thota, C. S.; Kondapaka, S.; Wimalawansa, S. J. Calcitonin generelated peptide in pregnancy and its emerging receptor heterogeneity. Trends in Endocrinology and Metabolism, 2002, 13(6), 263-269. 
[104] Martínez-Alvarez, O.; Guimas, L.; Delannoy, C.; Fouchereau-Peron, M. Occurrence of a CGRPlike molecule in siki (Centroscymnus coelolepsis) hydrolysate of industrial origin. Journal of Agricultural and Food Chemistry, 2007, 55(14), 5469-5475.

[105] Slizyte, R.; Mozuraityte, R.; Martínez-Alvarez, O.; Falch, E.; Fouchereau-Peron, M.; Rustad, T. Functional, bioactive and antioxidative properties of hydrolysates obtained from cod (Gadus morhua) backbones. Process Biochemistry, 2009, 44(6), 668-677.

[106] Picot, L.; Ravallec, R.; Fouchereau Peron, M.; Vandanjon, L.; Jaouen, P.; Chaplain-Derouiniot, M.; Guerard, F.; Chabeaud, A.; Legal, Y.; Martínez-Alvarez, O.; Bergé, J. P.; Piot, J. M.; Batista, I.; Pires, C.; Thorkelsson, G.; Delannoy, C.; Jakobsen, G.; Johansson, I.; Bourseau, P. Impact of ultrafiltration and nanofiltration of an industrial fish protein hydrolysate on its bioactive properties. Journal of the Science of Food and Agriculture, 2010, 90(11), 1819-1826.

[107] Ravallec-Plé, R.; Charlot, C.; Batista, I.; Van Wormhoudt, A.; Le Gal., Y.; Fouchereau Peron, M., The presence of bioactive peptides in hydrolysates prepared from processing waste of sardine (Sardina pilchardus). Journal of the Science of Food and Agriculture 2001, 81(11), 1120-1125.

[108] Rousseau, M.; Batista, I.: Le Gal, Y.; Fouchereau-Peron, M. Purification of a functional competitive antagonist for calcitonin gene related peptide action from sardine hydrolysates. Electronic Journal of Biotechnology, 2001, 4(1), 25-32.

[109] Dockray, G.J. Clinical endocrinology and metabolism. Gastrin. Best Practice \& Research Clinical Endocrinology \& Metabolism, 2004, 18(4), 555-568.

[110] Rehfeld, J.F. Cholecystokinin. Best Practice \& Research Clinical Endocrinology \& Metabolism, 2004, 18(4), 569-586.

[111] Cancre, I.; Ravallec, R.; Van Wormhoudt, A.; Stenberg, E.; Gildberg, A.; Le Gal, Y. Secretagogues and growth factors in fish and crustacean protein hydrolysates. Marine Biotechnology, 1999, 1(5), 489494.

[112] Thorkelsson, G.; Sigurgisladottir, S.; Geirsdottir, M.; Jóhannsson, R.; Guerard, F.; Chabeaud, A.; Bourseau, P.; Vandanjon, L.; Jaouen, P.; Chaplain-Derouiniot, M.; Fouchereau-Peron, M.; Martinez- 
Alvarez, O.; Le Gal, Y.; Ravallec-Ple, R.; Picot, L.; Berge, J.P.; Delannoy, C.; Jakobsen, G.; Johansson, I.; Batista, I.; Pires, C. In: Improving seafood products for the consumer; Borresen, T. Ed.; Woodhead Publishing Limited: Cambridge, 2008, pp. 363-398

[113] Lyapina, L.A.; Pastorova, V.E.; Samonina, G.E.; Ashmarin, I.P. The effect of PGP peptide and PGP-rich substances on haemostatic parameters of rat blood. Blood Coagulation \& Fibrinolysis, 2000, 11, $1-6$.

[114] Pastorova, V.E.; Lyapina, L.A.; Ashmarin, I.P.; Ostrovskaya, R.U.; Gudasheva, T.A.; Lugovskoi, E.V. Fibrin-Depolymerization Activity and the Antiplatelet Effect of Small Cyclic and Linear ProlineContaining Peptides. Biology Bulletin, 2001, 28(5), 504-507.

[115] Pastorova, V.E.; Lyapina, L.A.; Smolina, T.; Ashmarin, I.P. Anticoagulant and Fibrinolytic Effects of Certain Proline-Containing Peptides, Biology Bulletin, 1998, 3, 1-5.

[116] Lyapina, L.A.; Pastorova, V.E.; Obergan, T.Yu.; Samonina, G.E.; Ashmarin, I.P., Myasoedov, N.F. Comparison of anticoagulant effects of regulatory proline-containing oligopeptides. Specificity of glyprolines, semax, and selank and potential for their practical application. Biology Bulletin, 2006, 33(2), $153-161$

[117] Zhuikova, S.E.; Badmaeva, K.E.; Bakaeva, Z.V.; Samonina, G.E. Antiulcer Effects of the Tripeptide PGP and Its Possible Metabolites (PG, GP, Glycine, and Proline) in Different Models of Ulcer Induction in Rats. Biology Bulletin, 2004, 31(5), 484-487.

[118] Baglikova, K.; Trufanova, A.; Bakaeva, Z.; Samonina, G.; Andreeva, L.; Klimova, P.; Vas'kovsky, B. The influence of hydroxyproline- and proline-containing glyproline on ethanol-induced gastric lesions in rats. Moscow University Biological Sciences Bulletin, 2009, 64(1), 7-11.

[119] Badmaeva, S.E.; Kopylova, G.N.; Abushinova, N.N.; Samonina, G.E.; Umarova, B.A. The effect of glyprolines on stressogenic disorders in the rat behaviour. Russian Journal of Physiology, 2005, 91, (5), $543-550$

[120] Umarova, B.A.; Kopylova, G.N.; Smirnova, E.A.; Guseva, A.A.; Zhuikova, S.E. Secretory activity of mast cell during stress: Effect of prolyl-glycyl-proline and Semax. Bulletin of Experimental Biology and Medicine, 2003, 136(4), 325-327. 
[121] Watanabe, Y.; Sagara, Y.; Sugahara, K.; Kodama, H. Iminodipeptides containing proline with Cterminal and N-terminal residues prime the stimulation of human neutrophil superoxide generation by fMLP. Biochemical and Biophysical Research Communications 1994, 205(1), 758-764.

[122] Ruehl, M.; Somasundaram, R.; Schoenfelder, I., Farndale, R.W.; Knight, C.G.; Schmid, M.; Ackermann, R.; Riecken, E.O.; Zeitz, M.; Schuppan, D. The epithelial mitogen keratinocyte growth factor binds to collagens via the consensus sequence glycine-proline-hydroxyproline. Journal of Biological Chemistry, 2002, 277(30), 26872-26878.

[123] Postlethwaite, A.E.; Seyer J.M.; Kang, A.H. Chemotactic attraction of human fibroblasts to type I, II, and III collagens and collagen-derived peptides. Proceedings of the National Academy of Sciences of USA, 1978, 75(2), 871-875.

[124] Zhang, Z.; Wang, J.; Ding, Y.; Dai, X.; Li, Y. Oral administration of marine collagen peptides from Chum Salmon skin enhances cutaneous wound healing and angiogenesis in rats. Journal of the Science of Food and Agriculture, 2011, 91(12), 2173-2179.

[125] Zhu, C.-F.; Li, G.-Z.; Peng, H.-B.; Zhang, F.; Chen, Y.; Li, Y. Effect of Marine Collagen Peptides on Markers of Metabolic Nuclear Receptors in Type 2 Diabetic Patients with/without Hypertension. Biomedical and Environmental Sciences, 2010, 23(2), 113-120.

[126] Matsufuji, H.; Matsui, T., Angiotensin I-converting Enzyme Inhibitory Peptides in an Alkaline Protease Hydrolysate Derived from Sardine Muscle. Bioscience, Biotechnology, and Biochemistry, 1994, 58(12), 2244-2245.

[127] Iwai, K.; Hasegawa, T.; Taguchi, Y.; Morimatsu, F.; Sato, K.; Nakamura, Y.; Higashi, A.; Kido, Y.; Nakabo, Y.; Ohtsuki, K. Identification of food-derived collagen peptides in human blood after oral ingestion of gelatine hydrolysate. Journal of Agricultural and Food Chemistry, 2005, 53, 6531-6536.

[128] Ohara, H.; Matsumoto, H.; Ito, K.; Iwai, K.; Sato, K. Comparison of Quantity and Structures of Hydroxyproline-Containing Peptides in Human Blood after Oral Ingestion of Gelatine Hydrolysates from Different Sources. Journal of Agricultural and Food Chemistry, 2007, 55(4), 1532-1535. 
[129] Watanabe-Kamiyama, M.; Shimizu, M.; Kamiyama, S.; Taguchi, Y.; Sone, H.; Morimatsu, F.; Shirakawa, H.; Furukawa, Y.; Koma, M. Absorption and effectiveness of orally administered low molecular weight collagen hydrolysate in rats. Journal of Agricultural and Food Chemistry, 2010, 58(2), $835-841$.

[130] Meilman, E.; Urivetzky, M.M.; Rapoport, C.M. Urinary hydroxyproline peptides. Journal of Clinical Investigation, 1963, 42, 40-50.

[131] Aito-Inoue, M.; Lackeyram, D.; Fan, M.Z.; Sato, K.; Mine, Y. Transport of a tripeptide, Gly-ProHyp, across the porcine intestinal brush-border membrane. Journal of Peptides Science, 2007, 13, 468474. 